\title{
KECENDERUNGAN INTOLERANSI DAN PERAN PENDIDIKAN AGAMA DI SMA NEGERI YOGYAKARTA
}

\author{
Aniek Handajani ${ }^{1)}$, Noorhaidi Hasan ${ }^{2)}$ dan Tabita Kartika Christiani ${ }^{3)}$ \\ ${ }^{1}$ Interreligious Studies Sekolah Pascasarjana Universitas Gadjah Mada \\ ${ }^{2}$ Fakultas Pascasarjana Universitas Islam Negeri Sunan Kalijaga \\ ${ }^{3}$ Fakultas Teologi Universitas Kristen Duta Wacana \\ Email: ${ }^{1}$ aniek_handajani@yahoo.com, ${ }^{2}$ noorhaidi@hotmail.com, ${ }^{3}$ tabitachristiani@gmail.com
}

\begin{abstract}
Abstrak
Kecenderungan intoleransi dan praktik Islamisme di sekolah. Akan tetapi studi tentang proses radikalisasi dikalangan remaja sangat terbatas. Kami menyikapi masalah ini dengan menganalisa kecenderungan intoleransi, meneliti pelaksanaan pendidikan agama di sekolah dan mengungkapkan pergeseran kecenderungan intoleransi di kalangan siswa. Dengan memakai metode gabungan, studi ini mengungkap tujuh faktor yang mempengaruhi perubahan kecenderungan intoleransi agama di kalangan siswa yaitu: 1) para pemangku kepentingan merumuskan visi sekolah yang mendukung toleransi beragama; 2) kebijakan sekolah yang mendukung pluralisme dan toleransi terhadap agama lain di sekolah; 3) pemerintah dan pimpinan sekolah mengadakan pelatihan bagi para guru untuk memberikan pengetahuan dalam rangka mengatasi paham radikal; 4) guru mengintegrasikan kearifan lokal dalam bahan ajar mereka; 5) kegiatan siswa terutama Kerohanian Islam mengakomodasi keberagaman dan mendukung toleransi terhadap berbagai agama, etnis, dan budaya; 6) pengawasan terhadap buku dan materi dari internet yang mengandung doktrin radikal yang dilakukan oleh orang tua dan guru; 7) melibatkan organisasi mainstream Islam dalam melawan ideologi radikal dan memitigasi intoleransi di sekolah. Hasil penelitian ini menunjukkan potensi kontribusi pendidikan agama untuk mencegah intoleransi di sekolah.
\end{abstract}

Kata kunci: radikalisme, intoleransi, ajaran radikal, pendidikan agama

\begin{abstract}
Recently some surveys uncover the presence of intolerance tendency and Islamist practices in senior high schools. However, studies on 'radicalization' process among teenagers at school are still limited. We address the issue by analyzing intolerance tendency, examining the religious education at school and revealing the shift of intolerance tendency among students. By conducting mixed methods research in three public schools, this study uncovers seven factors that cause the shift of intolerance tendency: 1) stakeholders formulate school vision which endorses religious tolerance in public schools; 2) the school policies that support pluralism and tolerance towards other differences in the school environment; 3)government and school leaders conduct training to provide teachers with knowledge to counter radical teachings; 4) teachers integrate local wisdoms in their teaching materials; 5) the student activities particularly Islamic religious activities accommodate pluralism and endorse tolerance towards different religions, ethnics and cultures; 6) the supervision of books and materials from the internet that contain radical doctrines by parents and teachers; 7) involving Islamic mainstream organizations in countering radical ideology and mitigating intolerance in public schools. This research suggests the potential contribution of religious education to prevent intolerance at school.
\end{abstract}

Keywords: radicalism, intolerance, radical teachings, religious education 


\section{PENDAHULUAN}

Di era reformasi gerakan Islamisme yang sebelumnya berawal dari universitas telah menyebar ke sekolah menengah atas. Sebuah survei yang dilakukan pada tahun 2011 oleh Lembaga Kajian Islam dan Perdamaian (Oebaidillah, 2011) terhadap 590 responden (327 guru SMP dan 263 guru SMA) di Jakarta, Bogor, Depok, Tangerang, dan Bekasi (Jabodetabek) menunjukkan penyebaran ideologi Islamisme di kalangan guru agama Islam (Setyawan, 2016). Lebih lanjut sebuah survei yang diadakan oleh LaKIP pada tahun 2015 (dikutip oleh Dja'far, 2015) mengungkap adanya intoleransi dan sikap Islamisme yang menguat di kalangan guru dan siswa yang beragama Islam.

Studi di atas mengungkap adanya upaya sistematis proses "radikalisasi" yang dilakukan oleh kelompok radikal di kalangan SMA. Sayangnya penelitian mengenai remaja dan radikalisme masih terbatas (misalnya Kailani 2009, 2010; Wajidi, 2009; Salim dkk., 2011). Kailani (2010) mengungkap bagaimana kegiatan keagamaan Islam telah menjadi arena di mana identitas remaja Islam terbentuk di sekolah-sekolah di Yogyakarta dan sekitarnya. Sedangkan Wajidi (2009) mengungkap kegiatan keagamaan Islam yang berkembang di sekolah publik dalam rangka menciptakan lingkungan sekolah Islami berdasarkan pandangan agama tertentu. Sementara itu Salim dkk. (2011) menunjukkan intensitas dinamika ruang publik di sekolah negeri di mana dominasi agama yang ekslusif sebagai upaya menjadikan sekolah lebih "Islami" ditentang dan dinegosiasikan oleh siswa lainnya terutama di kalangan siswa Muslim.

Kecenderungan serupa dapat diamati di SMA negeri di Yogyakarta. Sebagian besar siswa perempuan mengenakan jilbab besar dengan rok panjang. Juga praktik-praktik Islamis tampak menonjol dalam kegiatan Organisasi Siswa Intra Sekolah (OSIS) dan kegiatan ekstrakurikuler lainnya, seperti melakukan pemisahan ketat antara siswa perempuan dan laki-laki di ruang publik, melakukan razia untuk memastikan siswi Islam mengenakan jilbab, dan mengadakan program induksi dan mentoring Islam untuk anggota Rohis. Praktek-praktek Islamis seperti ini menunjukkan bagaimana "radikalisasi" budaya sekolah dilakukan secara sistematis dalam bentuk kegiatan ekstrakurikuler dan kegiatan siswa lainnya.

Kami berpendapat bahwa penyebaran ideologi radikal di sekolah dapat dipahami dengan menganalisa kecenderungan intoleransi dan aspek-aspek pendidikan agama yang mempengaruhi siswa untuk menjadi intoleran. Penelitian ini dilakukan di tiga SMA negeri di Yogyakarta, yaitu SMAN 1 Yogyakarta, SMAN 3 Yogyakarta, dan SMAN 8 Yogyakarta. Berbeda dengan penelitian sebelumnya yang dilakukan di sekolah-sekolah ini, yang lebih berfokus pada kegiatan siswa, penelitian ini meneliti kecenderungan intoleransi dan mengeksplorasi kegiatan belajar mengajar Pendidikan Agama Islam di sekolah.

Berdasarkan konsep yang dikemukakan oleh Pak (1995: 122) bahwa ada dua faktor utama yang menyebabkan intoleransi yaitu: prasangka dan imej permusuhan. Dua faktor tersebut mempengaruhi persepsi siswa tentang agama lain. Dalam hal ini kelompok Islam radikal mendukung prasangka dan imej permusuhan dengan memanfaatkan ideologi Islamisme. Ideologi radikal ini menguatkan prasangka dan imej permusuhan terhadap penganut agama lain yang mengarah pada intoleransi beragama (Robinson, 2016). Akan tetapi baik intoleransi maupun toleransi dapat bervariasi bergantung pada faktor-faktor yang mempengaruhinya (Han, 1995; Stouffer dikutip Han, 1995). Toleransi ditanamkan dan dikembangkan melalui pendidikan dan pengalaman sosial namun dipengaruhi juga oleh kondisi sosial dan politik (Han, 1995). 
Gagasan utama kami adalah bahwa ideologi Islamisme memicu intoleransi di kalangan siswa SMA. Menurut Roy (2004: 58) Islamisme adalah "fundamentalisme politik Islam yang bertujuan mendirikan kembali masyarakat Islam sejati dengan menegakkan syariah dan mendirikan negara Islam melalui aksi politik". Lebih lanjut ia menegaskan bahwa "Islamisme bukan melulu agama tetapi ideologi politik yang dimaksudkan untuk membentuk kembali semua aspek dalam masyarakat yang diikuti oleh para aktor Islamisme" (Roy, 2004: p. 58). Sedangkan Kepel (dikutip dalam Hasan, 2012) mengklaim bahwa "Islamisme bukan hanya gejala keagamaan tetapi lebih merupakan fenomena sosial-politik yang melibatkan sekelompok Muslim yang aktif melakukan gerakan Islamisme berdasarkan ideologi tertentu yang mereka yakini".

Ada tiga faktor yang membedakan Islamisme dari fenomena sosial-politik lainnya, yaitu 1) aktor yang terlibat; 2) aktivitas dan 3) ideologi (Hasan, 2012). Aktor yang terlibat dalam Islamisme adalah sekelompok orang yang menggunakan identitas agama Islam sebagai sumber makna (acuan) yang dibangun oleh individu selama proses interaksi sosial dan mengikat seluruh anggota dalam gerakan Islamisme (Hasan, 2012). Akan tetapi identitas agama saja tidak cukup untuk menghubungkan seseorang dengan gerakan Islamisme jika dia tidak terlibat langsung dalam kegiatan tertentu. Gejala-gejala Islamisme muncul ketika dia aktif dalam gerakan politik tertentu yang memiliki spektrum luas terkait dengan sistem kekuasaan (Hasan, 2012). Ideologi menjadi sangat penting dalam Islamisme karena agenda politiknya yang terkait dengan sistem kekuasaan.

Dalam hal ini Islamisme berfungsi sebagai ideologi politik di mana syariah (hukum Islam) diterapkan dan negara Islam dapat didirikan (Hasan, 2012). Gagasan pemurnian dan pentingnya mempertahankan batas tegas antara 'kami' dan 'liyan' (yang lain) melekat dalam Islamisme (Roy, 2004: p. 126). Melalui slogan kembali ke model Islam murni - Al-Qur'an, Sunnah Nabi dan para sahabatnya - Islamisme terwujud dalam berbagai dimensi, dari identitas parokial hingga terorisme atas nama jihad (Hasan, 2012). Menurut Hasan dkk. (2013) Islamisme adalah ekspresi politikkeagamaan yang mencakup empat spektrum utama, termasuk militansi, radikalisme, ekstremisme, dan terorisme. Keempat spektrum menunjukkan gradasi bertahap kekuatan pengaruh Islamisme yang terpapar pada individu (Hasan, 2013).

Berdasarkan konsep spektrum Islamisme (Hasan, 2013), intoleransi adalah faktor kunci yang menyebabkan radikalisme, ekstremisme, dan terorisme. Apa itu intoleransi? Ada banyak konsep tentang intoleransi yang dikemukakan oleh para ilmuwan (Han, 1995; Pak, 1995, Lindsey dan Pausacker, 2016). Han (1995) mengungkapkan faktor-faktor yang mempengaruhi intoleransi. Sedangkan, konsep yang dikemukakan Pak mengungkap ciri-ciri penting intoleransi. Sementara itu Lindsey dan Pausacker meneliti penyebab utama intoleransi dalam studi kasus di Indonesia. Akan tetapi konsep-konsep ini tidak memberikan definisi tentang intoleransi agama. Sebaliknya Robinson (2016) mendefinisikan intoleransi agama sebagai "tidak menghormati hak asasi orang lain untuk memeluk keyakinan agama yang berbeda dari orang lainnya". Selain itu dia mengajukan tujuh bentuk intoleransi agama yaitu sebagai berikut: 1) menyebarkan informasi yang salah tentang kepercayaan atau praktik keagamaan suatu kelompok meskipun ketidak akuratan informasi tersebut dapat dengan mudah diperiksa dan diralat; 2) menyebarkan kebencian terhadap suatu kelompok; misalnya menyatakan bahwa semua anggota kelompok adalah jahat, berperilaku tidak bermoral, melakukan tindakan kriminal, dll.; 3) mengolok-olok dan meremehkan seluruh anggota kelompok agama karena kepercayaan dan praktik yang mereka anut; 4) 
berusaha untuk memaksakan keyakinan dan praktik keagamaan pada orang lain di luar kehendak mereka; 5) membatasi hak asasi manusia suatu kelompok agama; 6) merendahkan agama lain dianggap tidak berharga atau jahat; dan 7) menghambat kebebasan seseorang untuk berpindah agama.

Secara konseptual kami mengklaim bahwa kecenderungan intoleransi siswa muncul dari persepsi mereka tentang perbedaan (keberagaman) yang disebabkan oleh prasangka dan imej permusuhan. Kelompok radikal mendorong prasangka dan imej permusuhan dengan memakai doktrin agama berdasarkan ideologi Islamisme. Dengan menggunakan teori Islamisme yang dikemukakan oleh Hasan dkk. (2013) serta teori Robinson tentang intoleransi beragama, penelitian ini meneliti kecenderungan intoleransi di kalangan siswa, menganalisa aspek-aspek pendidikan agama dan mengeksplorasi peran Pendidikan Agama Islam di sekolah untuk mencegah intoleransi. Berdasarkan matriks Islamisme yang dikemukakan Hasan dan konsep Robinson, penelitian ini menetapkan kategori kecenderungan intoleransi yang terdiri dari dua puluh pernyataan, yaitu Item A, Item B dan Item C. Ketiga kategori ini menunjukkan tahapan pengaruh Islamisme pada seorang individu. Kedua puluh pernyataan tersebut ditujukan untuk menganalisa persepsi siswa tentang perbedaan/ keberagaman.

\section{METODE PENELITIAN}

Penelitian ini menggunakan metode gabungan dimana pendekatan kualitatif didukung oleh pendekatan kuantitatif (studi kasus dan survei). Studi kasus dilakukan dari Juli 2017 hingga Desember 2017 yang berfokus pada proses pembelajaran Pendidikan Agama Islam di sekolah-sekolah. Sedangkan penelitian survei dilakukan dari Februari 2018 hingga April 2018 dengan menitikberatkan pada kecenderungan intoleransi di kalangan siswa SMA. Penelitian ini menggunakan data kualitatif yang dikumpulkan dari observasi partisipan dan wawancara mendalam. Wawancara dilakukan terhadap siswa, guru, alumni, kepala sekolah dan wakil kepala sekolah. Ada 28 peserta, terdiri dari 13 perempuan dan 15 laki-laki, yang diwawancarai dalam Focus Group Discussion (Diskusi Kelompok Terarah, FGD) yang melibatkan antara 4 sampai 10 siswa.

Sedangkan populasi survei diambil dari sejumlah siswa dari tiga SMA negeri di Yogyakarta pada tahun akademik 2017-2018. Mereka adalah 964 siswa SMAN A Yogyakarta, 671 siswa SMAN B Yogyakarta dan 768 siswa SMAN C Yogyakarta. Dengan demikian jumlah total populasi penelitian ini adalah 2403 siswa. Dengan menggunakan purposive random sampling (sampling acak), survei dilakukan terhadap 195 responden dari tiga sekolah, dari kelas $\mathrm{X}$ hingga kelas XII siswa SMA, baik siswa laki-laki maupun perempuan. Survei ini diadakan melalui penyebaran kuesioner berdasarkan teori Hasan dan konsep intoleransi Robinson yang terdiri dari 20 pernyataan. Para siswa harus menanggapi pernyataan dalam kuesioner dengan memilih satu dari lima skala pernyataan: 1) sangat setuju; 2) setuju; 3) raguragu; 4) tidak setuju dan 5) sangat tidak setuju. Analisa data ditetapkan dengan margin kesalahan 10\% dan tingkat kepercayaan $90 \%$.

Penelitian ini menggunakan dua jenis program komputer untuk analisa data yaitu: program Excel dan Statistical Package for the Social Sciences (SPSS) Versi Siswa 23.0. Dengan menggunakan SPSS 23.0, peneliti dapat menganalisa data untuk menggambarkan kecenderungan umum tentang data (rata-rata, mode, median) dan penyebaran skor (varians, standar deviasi, rentang) dari masing-masing sekolah. Dengan demikian penelitian ini menerapkan statistik deskriptif untuk menggambarkan kecenderungan intoleransi siswa SMA. 


\section{HASIL DAN PEMBAHASAN}

Survei ini mengungkapkan bahwa sebagian besar siswa SMA negeri di Yogyakarta memiliki tingkat toleransi yang cukup tinggi. Berdasarkan hasil penelitian 25\% siswa SMAN A Yogyakarta memiliki tingkat toleransi yang tinggi. Sedangkan $74 \%$ siswa memiliki tingkat toleransi yang cukup tinggi dan hanya $1 \%$ siswa yang memiliki kecenderungan intoleransi. Di sisi lain, $45 \%$ siswa SMAN B Yogyakarta memiliki tingkat tolerransi yang tinggi, sedangkan 55\% siswa memiliki tingkat toleransi yang cukup tinggi dan tidak ada siswa yang intoleran. Sebaliknya 13\% siswa SMAN C Yogyakarta memiliki tingkat toleransi yang tinggi, $87 \%$ siswa memiliki tingkat toleransi yang cukup tinggi dan tidak ada siswa yang intoleran.

Selain itu berdasarkan respon siswa penelitian ini mengungkap bahwa sebagian besar siswa dari semua sekolah kurang rentan terhadap pernyataan pada Item A dan Item B. Akan tetapi sebagian besar siswa tidak rentan terhadap pernyataan pada Item C. Berdasarkan pernyataan pada Item A, survei ini mengungkap bahwa 23\% siswa dari semua sekolah yang berpartisipasi tidak rentan, $71 \%$ siswa kurang rentan dan $6 \%$ siswa rentan terhadap Item A. Sedangkan berdasarkan pernyataan pada Item $B$, survei menunjukkan bahwa $11 \%$ siswa tidak rentan, $68 \%$ siswa kurang rentan dan $21 \%$ siswa rentan terhadap Item B. Sebaliknya berdasarkan pernyataan pada Item $\mathrm{C}$ survei menunjukkan bahwa $83 \%$ siswa tidak rentan, $17 \%$ siswa kurang rentan dan tidak ada siswa yang rentan terhadap Item C.

Berdasarkan respon siswa dari semua sekolah yang berpartisipasi dalam survei menunjukkan bahwa tidak ada siswa yang rentan terhadap terorisme. Namun 6\% siswa rentan berdasarkan terhadap pernyataan pada Item A dan $21 \%$ siswa rentan terhadap pernyataan pada Item B. Hal ini berarti bahwa banyak siswa dari semua sekolah yang berpartisipasi terpapar dengan doktrin radikal meskipun hal itu tidak mengarah pada radikalisme. Demikian pula berdasarkan analisis SPSS, variabel radikalisme SMAN A Yogyakarta memiliki skor signifikansi (2tailed) 0,733> 0,05, oleh karena itu H0 diterima dan Ha ditolak. Ini berarti SMAN A Yogyakarta tidak memiliki kecenderungan radikalisme. Demikian juga analisa SPSS menunjukkan bahwa variabel terorisme SMAN A Yogyakarta memiliki skor signifikansi (2tailed) 0,890> 0,05, oleh karena itu H0 diterima dan Ha ditolak. Ini berarti bahwa tidak ada korelasi yang signifikan dari kecenderungan terorisme di kalangan siswa SMAN A Yogyakarta. Sedangkan, variabel intoleransi SMAN B Yogyakarta memiliki skor signifikansi (2-tailed) 0,733>0,05, oleh karena itu $\mathrm{H} 0$ diterima dan Ha ditolak.

Ini berarti bahwa SMAN B Yogyakarta tidak memiliki kecenderungan intoleransi. Selanjutnya output kedua menunjukkan bahwa variabel terorisme SMAN B Yogyakarta memiliki skor signifikansi (2-tailed) 0,609> 0,05, oleh karena itu H0 diterima dan $\mathrm{Ha}$ ditolak. Ini berarti bahwa tidak ada korelasi yang signifikan terhadap kecenderungan terorisme di kalangan siswa SMAN B Yogyakarta. Sementara itu variabel intoleransi SMAN C Yogyakarta memiliki skor signifikansi (2-tailed) 0,890>0,05, oleh karena itu H0 diterima dan Ha ditolak. Ini berarti bahwa SMAN C Yogyakarta tidak memiliki kecenderungan intoleransi. Sedangkan output (hasil) kedua menunjukkan bahwa variabel radikalisme SMAN C Yogyakarta memiliki skor signifikansi (2-tailed) 0,609>0,05, oleh karena itu H0 diterima dan Ha ditolak. Ini berarti bahwa ada korelasi yang signifikan terhadap kecenderungan radikalisme di kalangan siswa SMAN C Yogyakarta. Secara umum studi survei mengungkap bahwa siswa dari semua sekolah yang berpartisipasi tidak rentan terhadap radikalisme dan terorisme.

Berdasarkan konsep Robinson, respon siswa pada Item A dan Item B mengungkapkan persepsi mereka tentang perbedaan agama 
yang dapat dikategorikan ke dalam lima jenis intoleransi agama, yaitu: 1) menyebarkan informasi yang salah tentang keyakinan atau praktik keagamaan suatu kelompok meskipun ketidak akuratan informasi itu dapat dengan mudah diperiksa dan diralat; 2) menyebarkan kebencian terhadap anggota suatu kelompok; 3) mengolok-olok dan meremehkan seluruh anggota kelompok agama karena kepercayaan dan praktik yang mereka anut; 4) membatasi hak asasi manusia suatu kelompok agama dan 5) merendahkan agama lain dengan menganggap tidak berharga atau perbuatan jahat.

Berdasarkan respon siswa, doktrin keagamaan tertentu yang disetujui siswa sebagai berikut: 1) Ahmadiyah dianggap sesat dan menyesatkan karena itu harus dibubarkan (item 6); 2) memilih pemimpin masyarakat yang memeluk agama yang sama meskipun pemimpin agama yang berbeda lebih kompeten (item 7); 3) memberi selamat kepada orangorang dari agama lain (non-Muslim) saat perayaan hari besar agama mereka adalah tindakan yang membahayakan iman (item 3); 4) walaupun Indonesia terdiri dari berbagai suku, budaya dan agama, syariah Islam lebih penting untuk diterapkan dalam kehidupan bernegara karena mayoritas penduduknya adalah Muslim (item 2).

Secara garis besar penelitian ini mengungkap bahwa kecenderungan intoleransi di kalangan siswa sekolah menengah atas di Yogyakarta pada 2017 - 2018 cenderung menurun dibandingkan dengan survei sebelumnya yang diadakan oleh Lembaga Kajian Islam (Wajidi, Salim HS dan Kustiningsih, 2009). Survei sebelumnya menunjukkan bahwa $6,4 \%$ siswa SMA memiliki tingkat toleransi yang rendah, 69,2\% siswa memiliki tingkat toleransi yang cukup tinggi dan $24,3 \%$ siswa memiliki tingkat toleransi yang tinggi. Survei ini mengungkapkan bahwa $1 \%$ siswa memiliki tingkat toleransi yang rendah. Sedangkan $72 \%$ siswa memiliki tingkat toleransi yang cukup tinggi dan $27 \%$ siswa memiliki tingkat toleransi yang tinggi. Selain itu penelitian ini menunjukkan bahwa kecenderungan intoleransi yang tinggi di kalangan siswa SMAN A Yogyakarta, sedangkan tingkat intoleransi siswa di SMAN B Yogyakarta rendah. Sementara itu tingkat intoleransi di kalangan siswa SMAN C Yogyakarta di antara tingkat intoleransi SMAN A Yoyakarta dan SMAN B Yogyakarta.

Berdasarkan hasil penelitian survei, kami mendukung gagasan Han bahwa toleransi diperoleh melalui pendidikan dan lingkungan sosial. Seperti yang dinyatakan oleh UNESCO (1995) bahwa pendidikan penting untuk menumbuhkan toleransi, kehidupan harmonis dalam masyarakat yang terdiri dari berbagai suku, suku, adat, agama, jenis kelamin, usia dan budaya. Untuk lebih memahami penurunan tingkat intoleransi di kalangan siswa SMA, penting untuk membahas implementasi Pendidikan Agama Islam di sekolah-sekolah di bagian berikut.

\subsection{Pelaksanaan Pendidikan Agama Islam Di Sekolah Menengah Atas di Yogyakarta}

Berdasarkan Undang-Undang Sistem Pendidikan Nasional Nomor 20 Tahun 2003 semua sekolah menengah atas di Yogyakarta menerapkan kurikulum yang berlaku yaitu Kurikulum 2013. Oleh karenanya kebijakan sekolah, kurikulum sekolah dan silabus mengenai Pendidikan Agama Islam dirancang sebagaimana diamanatkan oleh Kurikulum 2013 dengan beberapa penyesuaian bergantung pada kebutuhan sekolah. Akan tetapi mengenai implementasi kebijakan sekolah sebagian besar ditentukan oleh manajemen sekolah dan warga sekolah, yaitu kepala sekolah, wakil kepala sekolah, guru dan siswa.

Struktur kurikulum SMA dikembangkan berdasarkan peraturan Menteri Pendidikan dan Kebudayaan Nomor 59 Tahun 2014 tentang Kerangka Dasar dan Struktur Kurikulum untuk Sekolah Menengah Atas yang terdiri dari struktur kurikulum mata pelajaran wajib, mata 
pelajaran peminatan dan mata pelajaran lintas minat. Berdasarkan pada struktur kurikulum sekolah menengah atas, Pendidikan Agama termasuk kelompok Mata Pelajaran Wajib yang dialokasikan tiga jam pelajaran per minggu untuk kelas X, XI dan XII. Satu jam pelajaran berlangsung selama empat puluh lima menit.

Berdasarkan kebijakan sekolah, Pendidikan Agama Islam dilakukan di dalam dan di luar jam sekolah baik sebagai program intra-kurikuler maupun ekstrakurikuler. Dalam hal ini pengajaran agama Islam di kelas termasuk kegiatan intra-kurikuler yang dilaksanakan pada jam sekolah. Sedangkan kegiatan ekstrakurikuler diatur berdasarkan kebijakan sekolah di luar jam sekolah di bawah pengawasan wakil kepala sekolah urusan kesiswaan. Jadi semua kegiatan belajar mengajar di sekolah dikelola berdasarkan kebijakan sekolah termasuk misalnya Tata Tertib Siswa, Ketentuan Pakaian, Kegiatan Razia Tata Tertib dan lainnya.

Secara umum semua sekolah SMA memiliki kebijakan sekolah tentang kegiatan keagamaan yaitu Tadarus Al-Qur'an dan Program Mentoring yang dilakukan oleh Kerohanian Islam (Rohis). Di SMAN B Yogyakarta Tadarus diadakan pada hari Jumat pagi sebelum pelajaran mulai. Sedangkan di SMAN A Yogyakarta dan SMAN C Yogyakarta Tadarus dilakukan setiap pagi dari Senin hingga Jumat sebelum pelajaran. Sedangkan program Mentoring dilakukan pada hari Jumat secara bergantian antara siswa lakilaki dan perempuan. Para siswa laki-laki mengikuti program Mentoring pukul 12.00 13.00 siang, sedangkan siswa perempuan pada pukul 13.00 - 14.00 siang. Siswa perempuan mengikuti program Mentoring Rohis, sedangkan siswa laki-laki shalat Jumat begitu sebaliknya.

Di SMAN A Yogyakarta wakil kepala sekolah dibantu oleh Komisi 'Stabilisasi dan Kedisiplinan' (Komisi 3) OSIS melakukan razia untuk menegakkan kedisiplinan siswa. Di pagi hari komisi ini merazia siswa yang tidak mengenakan seragam yang sesuai peraturan baik siswa Muslim dan non-Muslim, sementara pada sore hari mereka merazia siswa Muslim yang tidak shalat Dhuhur di masjid. Khususnya siswa Muslimah perempuan diharuskan mengenakan jilbab, kemeja lengan panjang dan rok panjang. Sementara itu di SMAN B Yogyakarta mengenakan jilbab, atasan lengan panjang dan rok panjang untuk siswi Islam adalah pilihan. Hanya pada hari Senin semua siswa harus mengenakan kemeja lengan panjang, sedangkan pada hari Selasa dan Rabu siswa laki-laki dan perempuan mengenakan kemeja lengan pendek. Jelaslah kebijakan sekolah mendukung kebebasan berekspresi tanpa memandang agama, suku, dan budaya siswa. Di sisi lain di SMAN C Yogyakarta kebijakan sekolah mengharuskan semua siswi Islam untuk memakai kemeja lengan panjang dan rok panjang. Khususnya bagi siswi Muslimah diwajibkan mengenakan jilbab, kemeja lengan panjang, dan rok panjang. Akan tetapi banyak siswi Islam tidak mengenakan jilbab di lingkungan sekolah.

Mengenai materi pelajaran buku bacaan utama Pendidikan Agama Islam yang digunakan di SMA berjudul "Pendidikan Agama Islam dan Budi Pekerti untuk SMA / MA / SMK / MAK untuk kelas X, XI dan XII" yang diterbitkan oleh 'Pusat Kurikulum dan Perbukuan, Badan Penelitian dan Pengembangan Kementerian Pendidikan dan Kebudayaan. Penggunaan buku pelajaran berdasarkan ketentuan dari Departemen Pendidikan dan Kebudayaan dan Departemen Agama dan persetujuan dari 'Musyawarah Guru Pendidikan Agama Islam di DI Yogyakarta. Sedangkan sebagai buku pendukung guru agama Islam di setiap sekolah menggunakan buku yang berbeda. Di SMAN A Yogyakarta guru agama Islam menggunakan Al-Qur'an, Hadits dan Tafsir Al-Maroghi. Sedangkan, di SMAN B Yogyakarta guru memakai Tafsir Ibnu Katsir dan Riyadush Sholihin selain Al-Qur'an dan Hadits. 
Sementara itu di SMAN C Yogyakarta guru memakai Al-Qur'an dan Hadits dan juga Tafsir Al-Qur'an yang ditulis oleh Quraish Shihab.

Disamping buku teks guru agama Islam di SMAN A dan SMAN B Yogyakarta juga menggunakan "Lembar Kegiatan Siswa" (LKS) , materi dari TV dan internet. LKS dikembangkan oleh guru berdasarkan Kurikulum 2013. Sebaliknya di SMAN C Yogyakarta guru tidak menggunakan LKS tetapi hanya mencari bahan dari internet. Penggunaan LKS di sekolah memiliki manfaat yaitu materi yang diberikan oleh guru sesuai dengan silabus yang ditetapkan dalam kurikulum 2013. Sedangkan guru yang hanya meminta siswa untuk mencari materi di internet memiliki kerentanan untuk menemukan konten materi yang radikal.

Mengenai ketersediaan literatur Islam, penelitian ini mengungkapkan bahwa ada tiga jenis literatur Islam yang beredar di kalangan siswa SMA yaitu: ideologis, puritan (Salafi) dan kesalehan populer. Tipe ideologis ditemukan dalam literatur Islam tentang Jihad, Tahriri dan Tarbawi (Ikhwan dikutip Hasan, 2018). Meskipun terdapat beberapa buku yang mengandung konten radikal di perpustakaan sekolah, sebagian besar siswa dari semua sekolah yang diteliti cenderung membaca literatur populer sedangkan hanya beberapa siswa membaca literatur Tahriri. Akan tetapi ketersediaan literatur Jihadi, Salafi, Tahriri dan Tarbawi di sekolah memungkinkan siswa untuk mengakses buku-buku tersebut. Demikian juga buku-buku yang direkomendasikan oleh alumni selama program Mentoring juga memberikan kesempatan bagi siswa untuk mengakses ideologi radikal.

Selain bahan ajar, strategi mengajar dan kualitas guru juga penting dalam menghadapi radikalisme. Akan tetapi banyak guru yang kurang memiliki pengetahuan untuk menghadapi ajaran radikal. Kompetensi guru dalam memakai strategi pengajaran yang dapat mencegah penyebaran ideologi radikal masih rendah. Guru agama cenderung salah mengartikan istilah "Pendidikan Agama" dengan istilah "Pendidikan Keagamaan" sebagaimana yang diatur dalam UndangUndang Sistem Pendidikan Nasional Nomor 20 Tahun 2003. Kesalahpahaman mengenai dua konsep yang berbeda ini mengarahkan mereka untuk mengajar "Pendidikan Keagamaan" yang menekankan penguasaan siswa terhadap agama mereka dan mempraktikkan ajaran agama mereka, bukannya "Pendidikan Agama" yang berfokus pada pembangunan "kepribadian siswa dan mampu menjaga perdamaian, diantara sesama penganut agama dan antar umat beragama lain secara harmonis" (Bab II pasal 2 ayat 1 Peraturan Pemerintah No. 55). Kecenderungan ini telah membuka peluang yang meluas bagi proses "Islamisasi" di sekolah.

Ada dua hal penting yang mendukung proses radikalisasi di sekolah: kebijakan sekolah dan penyebaran gerakan Islamisme (Salim dkk. 2011: 23). Kebijakan sekolah mewajibkan pendidikan agama tidak sekedar mata pelajaran yang diajarkan oleh guru agama di dalam kelas melainkan juga tuntutan untuk mempraktikkan ajaran agama di hampir semua kegiatan akademik. Hal ini menunjukkan bagaimana gerakan Islamisme telah mendominasi ruang publik di SMA. Sementara ruang publik sekolah idealnya dapat mengakomodasi berbagai ekspresi warga sekolah tanpa memandang agama, etnis dan budaya dan berfungsi sebagai tempat belajar dalam mengelola pluralisme (Salim dkk., 2011: 13-14).

Menurut Dja'far (2015) sikap intoleransi di kalangan guru dan siswa SMA disebabkan oleh tiga faktor. Pertama, ketidakmampuan para pemangku kepentingan untuk merumuskan visi sekolah yang mendukung toleransi beragama di SMA. Kedua, para pimpinan sekolah dan guru yang sebagian besar adalah pegawai negeri memiliki kesulitan dalam membedakan antara kepercayaan pribadi dan nilai-nilai agama universal. Oleh karenanya beberapa kepala 
sekolah dan guru dengan mudah mendiskriminasi orang yang berbeda agama dan kepercayaan. Ketiga, tidak adanya peran organisasi keagamaan moderat seperti Nahdlatul Ulama, Muhammadiyah, PGI, KWI, komunitas kelompok kepercayaan menyebarkan ajaran agama mainstream di kalangan siswa di SMA.

Kecenderungan intoleransi juga dipengaruhi oleh kesalahpahaman tentang tujuan pendidikan nasional (pasal 1 ayat $2 \mathrm{UU}$ Sistem Pendidikan Nasional). Dalam pasal ini pendidikan nasional didefinisikan sebagai "pendidikan berdasarkan Pancasila dan Undang-Undang Dasar Negara Republik Indonesia 1945 yang berakar pada nilai-nilai agama, budaya nasional Indonesia dan responsif terhadap tuntutan perubahan zaman". Dalam praktiknya, kata "nilai-nilai agama" dilakukan dengan menerapkan nilai agama mayoritas, padahal itu sebenarnya adalah "nilai-nilai agama universal". Oleh karena itu banyak sekolah umum menjadikan ritual keagamaan tertentu sebagai program keunggulan bagi siswa. Beberapa kepala sekolah bahkan menganggap bahwa sekolah negeri yang berhasil dan berkualitas harus menjadi sekolah agama. Sayangnya nilai-nilai agama yang diterapkan di sekolah-sekolah umum ini hanya diambil dari satu agama (Dja'far, 2015).

Akibatnya di sekolah SMA 'praktik Islamisme muncul dalam kegiatan OSIS dan kegiatan ekstrakurikuler lainnya, seperti misalnya pemisahan antara siswa laki-laki dan perempuan dalam pertemuan OSIS dan dalam kegiatan Pramuka, larangan berjabat tangan di antara siswa laki-laki dan perempuan yang bukan "muhrim" (saudara kandung) mereka, melakukan razia untuk membuat siswi Islam mengenakan jilbab dan mengadakan "Malam Bina Iman dan Taqwa" (Mabit) untuk Islam Kerohanian (Rohis). Pada kenyataannya program-program ini telah menjadi tradisi sekolah SMA selama beberapa tahun terakhir (Salim dkk, 2011: 21).
Oleh karenanya pemerintah dan para pimpinan sekolah mengadakan pelatihan bagi para guru untuk melawan gerakan Islamisme. Manajemen sekolah mendukung pemahaman multikultural dengan memasukkan konten kurikulum lokal, seperti pendidikan bahasa Jawa dan pelajaran membatik sebagai mata pelajaran tambahan. Juga para kepala sekolah merumuskan visi sekolah yang mendukung toleransi dan pluralisme serta menetapkan kegiatan Pramuka sebagai ekstrakurikuler wajib dalam rangka pembentukan karakter siswa. Selain itu para kepala sekolah mengharuskan guru untuk mengintegrasikan kearifan lokal dalam mata pelajaran yang diajarkan di kelas. Selanjutnya untuk mencegah penyebaran ideologi radikal melalui Rohis, mentoring dilakukan oleh siswa dan alumni di bawah pengawasan guru dan wakil kepala sekolah urusan kesiswaan.

\subsection{Peran Pendidikan Dalam Mencegah Intoleransi}

Untuk menghadapi penyebaran ideologi radikal di sekolah-sekolah, pemerintah telah melakukan banyak program. Pemerintah telah meluncurkan kurikulum yang bertujuan untuk meningkatkan kompetensi siswa dan mendukung pembentukan karakter. Pemerintah juga telah menetapkan kebijakan pendidikan yang mempromosikan kerja sama di antara orang-orang dari berbagai agama, suku, dan budaya. Selain itu pemerintah telah mengadakan pelatihan untuk guru dari berbagai mata pelajaran, khususnya guru agama. Namun pemerintah kurang melakukan pengawasan terhadap pelaksanaan program. Selain itu konten kurikulum kurang menekankan multikulturalisme dan toleransi antar agama. Dengan demikian terlepas dari upaya pemerintah dalam meningkatkan kualitas pendidikan dan mendukung ajaran agama yang damai, dalam praktiknya ajaran agama radikal masih tersebar luas di kalangan siswa, guru dan masyarakat.

Ada sejumlah langkah yang bisa diambil untuk mengatasi intoleransi. Pertama, 
mengutamakan nilai keanekaragaman di sekolah SMA. Sekolah harus menjadi tempat yang strategis untuk membangun kesadaran akan keberagaman dan toleransi. Upaya dapat dilakukan dengan meningkatkan kapasitas kepala sekolah, guru, termasuk pejabat di dinas pendidikan atau kementerian pendidikan. Kedua, meningkatkan partisipasi orang tua untuk memastikan bahwa anak-anak mereka tidak mengalami diskriminasi atau mengikuti pemahaman yang intoleran. Selain itu sekolah juga dapat memaksimalkan peran forum guru. Forum guru dapat menjadi tempat di mana para guru dapat bersama-sama mencari solusi untuk menumbuhkan nilai toleransi. Ketiga, menetapkan pola audit kinerja internal di sekolah. Dalam hal ini prinsip layanan nondiskriminasi dapat dimasukkan dalam prinsip akuntabilitas dan transparansi sebagai salah satu indikator keberhasilan sekolah. Keempat, bekerja sama dengan organisasi keagamaan moderat di Indonesia untuk memperkuat nilainilai keragaman di sekolah.

Oleh karenanya pemerintah Indonesia seharusnya melibatkan organisasi massa Islam moderat, seperti Nahdlatul Ulama, Muhammadiyah, al-Irsyad, dan Persatuan Islam (Persatuan Islam, Persis), yang mengelola berbagai lembaga pendidikan di jenjang yang berbeda, untuk menangani penyebaran ideologi radikal di akar rumput. Organisasi-organisasi ini diharapkan menumbuhkan nilai-nilai multikultural dan demokratis serta toleransi antar agama di sekolah. Juga para pemimpin agama diharapkan dapat memainkan peran utama dalam mengoreksi interpretasi yang salah tentang ajaran agama Islam untuk mendelegitimasi ideologi radikal. Sementara pendekatan keamanan yang diterapkan oleh pemerintah mungkin efektif dalam menangani serangan teroris, pendekatan lunak (soft approach) melibatkan masyarakat sipil yang dikenal sebagai 'Strategi Populasi-Sentris' dalam meningkatkan kesadaran di kalangan masyarakat untuk mendukung setiap upaya mendelegitimasi radikalisme (Hasan, 2012). Disamping itu kolaborasi antara kelompok masyarakat sipil dan Departemen Pendidikan telah menghasilkan pengembangan modul perdamaian (termasuk modul tentang menghargai perbedaan agama) dan pelatihan tentang pendidikan perdamaian bagi petugas TU sekolah dan guru di SMA. Upaya-upaya ini tentu saja membantu membangun budaya damai yang mendukung kerja sama antar umat beragama.

\section{KESIMPULAN}

Penelitian ini mengungkapkan bahwa $1 \%$ siswa memiliki tingkat toleransi yang rendah, sedangkan $72 \%$ siswa memiliki tingkat toleransi yang cukup tinggi dan $27 \%$ siswa memiliki tingkat toleransi yang tinggi. Selain itu sebagian besar siswa SMA negeri memiliki tingkat toleransi yang cukup tinggi. Penelitian ini juga menunjukkan bahwa kecenderungan intoleransi di kalangan siswa SMAN A Yogyakarta tinggi, sedangkan di SMAN B Yogyakarta tren intoleransinya rendah. Sementara itu intoleransi di kalangan siswa SMAN C Yogyakarta terletak di antara tingkat intoleransi SMAN A Yogyakarta dan SMAN B Yogyakarta.

Berdasarkan temuan penelitian ada beberapa faktor yang menyebabkan penurunan kecenderungan intoleransi. Pertama, para pemangku kepentingan merumuskan visi sekolah yang mendukung toleransi beragama di sekolah umum. Kedua, kebijakan sekolah yang mendukung pluralisme dan toleransi terhadap perbedaan agama di lingkungan sekolah. Ketiga, pemerintah dan para pemimpin sekolah melakukan pelatihan bagi para guru dalam rangka memberikan pengetahuan untuk melawan ajaran radikal. Guru mengintegrasikan kearifan lokal dalam bahan ajar mereka. Keempat, kebijakan sekolah yang mendukung toleransi. Kelima, kegiatan kesiswaan, terutama kegiatan Rohis, yang mengakomodasi pluralisme dan mendukung toleransi terhadap berbagai agama, suku, dan budaya. Keenam, pengawasan 
terhadap buku dan bahan dari internet yang mengandung doktrin radikal oleh orang tua dan guru. Ketujuh, melibatkan organisasi arus utama Islam dalam melawan ideologi radikal dalam rangka memitigasi intoleransi di sekolah SMA.

Dengan demikian Pendidikan Agama Islam (PAI) memainkan peran penting dalam mencegah penyebaran ideologi radikal. Ada sejumlah langkah yang bisa diambil untuk mengatasi intoleransi melalui pendidikan. Pertama, mengutamakan nilai keanekaragaman di sekolah. Kedua, melibatkan orang tua untuk mencegah diskriminasi dan intoleransi di kalangan siswa. Ketiga, mengadakan audit kinerja internal di sekolah. Keempat, melibatkan organisasi keagamaan moderat seperti NU dan Muhammadiyah untuk menangkal penyebaran ideologi radikal. Kelima, kolaborasi antara kelompok masyarakat sipil dan Departemen Pendidikan dalam melawan doktrin radikal dengan membuat modul dan pelatihan pendidikan perdamaian. Keenam, sangat penting bagi pemerintah untuk menerapkan kebijakan pendidikan yang memfasilitasi pemahaman tentang sejarah bangsa, mempromosikan toleransi antar budaya dan antar agama, mendukung pembentukan karakter dan membekali generasi muda dengan pengetahuan dan keterampilan untuk menghadapi tantangan dunia global.

Oleh karenanya penting bagi pemerintah menggunakan segala cara yaitu melalui pendidikan formal (seperti sekolah, universitas) dan pendidikan informal (seperti pertemuan keagamaan, publikasi, media massa, internet). Dengan demikian pertanyaan penting yang perlu diatasi di tingkat regional adalah bagaimana sekolah berbasis kurikulum mendukung kearifan lokal yang dapat mencegah radikalisme dan mempromosikan toleransi antar budaya dan antar pemeluk agama. Oleh sebab itu sangat penting untuk menemukan cara bagaimana tradisi lokal seperti cerita rakyat, kerajinan tangan, tarian tradisional, dapat digunakan sebagai bahan pengajaran dan desain silabus yang dimuat dalam kurikulum sekolah.

\section{REFERENSI}

Dja'far, Alamsyah M, Intoleransi Kaum Pelajar, (Jakarta: The Wahid Institut), 2015.

Han, Wan- Sang. The issue of Tolerance as an Element of Peaceful Unification of the Korean Peninsula, UNESCO, Democracy and Tolerance: Proceedings of the International Conference Seoul, Republic of Korea, 27-29 September 1994, Seoul: the Korean National Commission for UNESCO, 1995, pp. xv - Xxv.

Hasan, Noorhaidi (ed). Literatur Keislaman Generasi Milenial: Transmisi, Apropriasi, dan Kontestasi, Yogyakarta: Pascasarjana UIN Sunan Kalijaga Press, 2018.

Hasan, Noorhaidi dkk., Narasi dan Politik Identitas: Pola Penyebaran dan Penerimaan Radikalisme dan Terorisme di Indonesia, Laporan Penelitian, Yogyakarta: Fakultas Syariah dan Hukum UIN Sunan Kalijaga bekerjasama dengan FKPT dan BNPT, 2013.

Hasan, Noorhaidi, Islam Politik di Dunia Kontemporer: Konsep, Genealogi, Teori. Yogyakarta: Sunan Kalijaga Press, 2012.

Ikhwan, Munirul, Produksi Wacana Islam (IS) di Indonesia: Revitalisasi Islam Publik dan Politik Muslim, Noorhaidi Hasan (ed), Literatur Keislaman Generasi Milenial: Transmisi, Apropriasi, dan Kontestasi, Yogyakarta: Pascasarjana UIN Sunan Kalijaga Press, 2018, pp.63108.

Kailani, Najib. " Kami Adalah Mujahidin Berpedang Pena: Studi Gerakan Dakwah Forum Lingkar Pena Yogyakarta", Thesis MA, Jurusan Antropologi, 
Fakultas Ilmu Budaya, Universitas Gadjah Mada, 2009.

Kailani, Najib. "Muslimising Indonesian Youths: The Tarbiyah Moral and Cultural Movement in Contemporary Indonesia, in Madinier, Remy (ed), Islam and the 2009 Indonesian Elections, Political and Cultural Issues: The Case of Prosperous Justice Party $(P K S)$, Bangkok: Institut de Recherche sur l'Asie du Sud-Est Contemporaine (IRASEC), 2010.

Kemendikbud, Pendidikan Agama Islam dan Budi Pekerti untuk SMA/MA/SMK/MAK Kelas XII, Edisi Revisi 2012, Jakarta: Kementerian Pendidikan dan Kebudayaan, 2015.

Kementerian Pendidikan dan Kebudayaan Republik Indonesia, Pendidikan Agama Islam dan Budi Pekerti untuk SMA/MA/SMK/MAK Kelas XI, edisi revisi, Jakarta: Kementerian Pendidikan dan Kebudayaan, 2017.

Kepel, Gilles, Jihad: The trail of Political Islam, London: Belknap/Harvard Press, 2002.

Lindsey, Tim and Helen Pausacker. Religion, Law and Intolerance in Indonesia. London/New York: Routledge, 2016.

Oebaidillah, Syarief, Intoleransi Guru dan Siswa Mencemaskan, Media Indonesia, minggu, 27 februari 2011, No.10952, tahun XLII hal. 1. Available at http://mirror.unpad.ac.id/koran/mediaind onesia/mediaindonesia.2011.02.27.pdf

Pak, Chi Young. Prejudice and Enemy as a Source of Intolerance, UNESCO, Democracy and Tolerance: Proceedings of the International Conference Seoul, Republic of Korea, 27-29 September 1994, Seoul: the Korean National Commission for UNESCO, 1995, pp. xv $-\mathrm{xxv}$.

Peraturan Pemerintah Republik Indonesia Nomor 55 Tahun 2007 Tentang
Pendidikan Agama dan Pendidikan Keagamaan.

Available

at

http://kelembagaan.ristekdikti.go.id/wpcontent/uploads/2016/08/PP 55 2007-

Pendidikan-Agama-Keagamaan.pdf

Peraturan Menteri Pendidikan dan Kebudayaan Nomor 59 Tahun 2014 Tentang Kerangka Dasar dan Struktur Kurikulum Sekolah Menengah Atas dan Madrasah Aliyah.

Robinson, Bruce A. 2016. "Religious Intolerance", Viewed from http://www.religioustolerance.org/relint ol1.htm\#def, on 3 February 2018

Roy, Oliver, The Failure of Political Islam, Cambridge: Harvard University Press, 1996.

Salim HS, Hairus; Najib Kailani and Nikmal Azekiyah, Politik Ruang Publik Sekolah: Negosiasi dan Resistensi di Sekolah Menengah Umum Negeri di Yogyakarta. Tim Peneliti Yayasan Lembaga Kajian Islam dan Sosial (LkiS) dan Pusat Studi Sosial Asia Tenggara (PPSAT) UGM, Yogyakarta: Center for Religious and Cross-Cultural Studies/CRCS, 2011.

Setyawan, Davit. Inflasi Radikalisme: Amankah Anak Kita Bersekolah. 25 Januari 2016 at http://www.kpai.go.id/utama/inflasiradikalisme-amankah-anak-kitabersekolah/

Undang-Undang Republik Indonesia Nomor 20 Tahun 2003 Tentang Sistem Pendidikan Nasional

http://pendis.kemenag.go.id/file/dokumen/uun o20th2003ttgsisdiknas.pdf

UNESCO, Democracy and Tolerance: Proceedings of the International Conference Seoul, Republic of Korea, 27-29 September 1994, Seoul: the Korean National Commission for UNESCO, 1995. 
Volume 71, Nomor 2, 1 Desember 2019

Wajidi, Farid, Salim HS, Hairus, and Kustiningsih, Wahyu, Toleransi Siswa di DIY: Laporan Survei: Yogyakarta, LKiS-Hivos, 2009. 